DOI https://doi.org/10.30525/978-9934-26-173-2-45

\title{
AVIATION ENGLISH IN THE SYSTEM OF PROFESSIONAL EDUCATION
}

\author{
Piven V. V. \\ Ph. D, Assistant Professor \\ Foreign Languagies Department \\ Flight Academy of National Aviation University of Ukraine \\ Kropyvnytskyi, Ukraine
}

The article deals with the problem of professional training of pilots in the context of teaching aviation English. Various methods and technologies are proposed for the development of reliable knowledge, skills and abilities in the process of training the radio communication in English and English-language discourse.

Recently the requirements for Aviation English knowledge has tightened due to aviation industry growth and development. Accordingly, the demands for the professional training of aviation specialists (especially pilots and air traffic controllers) have increased, where stability and reliability in the process of professional activity come first. We consider this problem in the context of training aviation specialists in English, as an integral part of highly qualified professionals training. [1]

Aviation English communication means first of all encompasses written, oral, visual and digital communication within an aviation context. This concept blends together pedagogical principles of rhetoric, technology, software, and learning theory to improve and deliver communication in a variety of settings ranging from technical writing to usability and digital media design. It is a concept that focuses on the study of information and the ways it is created, managed, distributed, and consumed. [2] This creates a demand for skilled communicators which continues to exceed the supply of trained professionals, such as air traffic controllers, pilots, flight managers, search and rescue specialists, cabin crews etc. To make the requirements for knowledge of the Aviation English language universal all over the world, an International Organization of Civil Aviation (ICAO) provided special system of Aviation English certification. It implemented a mandatory procedure for passing the exam for proficiency in Aviation English. The grading system provides 6 levels. The knowledge of the 4-th level is necessary for aviation specialists to be admitted to the workplace. [3]

The field of professional communication (in our case Aviation English) is closely related to technical communication, though professional 
communication encompasses a wider variety of skills. Professional communicators use strategies, learning theory, and technologies to more effectively communicate in the professional world, which includes the sphere of aviation. Successful communication skills are critical to aviators. Is teaching aviation English different from teaching general English? This often stems from the perception that teaching aviation English is the same thing as teaching general English. In fact, it's more about helping learners develop their English skills for use in aviation context. Special attention should be paid to radiotelephony communication training, because it is one of the most important skills for pilots and air traffic controllers in the process of providing flight safety. [1]

First of all, it is necessary to identify the purpose of students teaching [4]. As for specification for aviators teaching we should pay attention that very often we teach not only young students but busy adults who are used to working towards objectives. We should therefore discuss with them at the beginning of the course what they would realistically like to achieve. This usually means breaking things down into skills. This 'needs analysis' can be shared with the learners and referred to as a way of keeping them engaged and motivated throughout the course. Bear in mind that their jobs are really specific. The teacher and instructors should keep in mind this factor.

Secondly, adopt your materials for different level of students. Students will expect you to bring different materials to class. There are lots of books and online resources available, but it's important to choose materials that create 'authentic' situations in the classroom, in our case real standard and emergency situations from the history of aviation are preferable. Probably the most important resource is the learners themselves, especially if they are experienced pilots or air traffic controllers. They can provide you with real materials from their working lives - the things they need to discuss and understand, or perhaps even create and present possible situation. [5] These could be leaflets, aviation incidents and accidents, internet information, which they can present in reports, case-situations or discussions. Students will probably expect you to take some of these resources and create your own worksheets from them. By the way, experience has proven that exactly case - method in pilots and air traffic controllers is one of the most effective in teaching aviation English. Don't forget: concentrate on goals and needs. Find out why these resources are important and what your students want to take away from the lesson. Then come to an agreement with them about how to meet these needs and try to discuss this problem together. Also, we should consider all these aspects in the process of teaching students of different aviation professions. So, the achievement of the main goal in the process of aviation specialists training has become in a priority today - the development 
of reliable professional skills in modern aircraft operation when conducting radio communication exclusively in English.

\title{
References:
}

1. Sue E., Terence G. English for Aviation (for Pilots and Air Traffic Controllers) / E. Sue, G. Terence, Oxford. 2001.95 p.

2. Harwood N. English Language Teaching. Materials, Theory and Practice/N. Harwood, Cambridge University Press. 2010. 488 p.

3. Hedge T. Teaching and Learning in the Language Classroom: A Guide to Current Ideas about the Theory and Practice of English Language Teaching/T. Hedge, Oxford. 2000. 464 p.

4. Cook, G. Discourse, Oxford University Press. 1989. 385p.

5. Мартынова Р. Ю. Педагогические основы интегрированного обучения образовательной и иноязычной речевой деятельности студентов неязыковых специальностей : монография. Одесса: «Освіта України». 2017. 208 с.

DOI https://doi.org/10.30525/978-9934-26-173-2-46

\section{ФОРМУВАННЯ ПСИХОФІЗІОЛОГІЧНОЇ НАДІЙНОСТІ МАЙБУТНІХ АВІАЦІЙНИХ ФАХІВЦІВ В КОНТЕКСТІ КОМПЕТЕНТНІСНОГО ПІДХОДУ}

\author{
Півень М. I. \\ кандидат педагогічних наук, дочент, \\ завідувач кафедри фізичної та психофізіологічної підготовки \\ Льотна академія Національного авіачійного університету \\ м. Кропивницький, Украӥна
}

Інтерес до феномену «психофізіологічна надійність» як до дидактичного конструкту якісної професійної освіти пояснюється розробкою проблем психологічної готовності курсантів-пілотів до льотної діяльності [1]. Широке коло наукових досліджень і багатолітня практика системної організації фізичної підготовки свідчить, що одним 3 можливих вирішень надзвичайно актуальної для льотної практики проблеми формування психофізіологічної надійності курсантів льотного ЗВО $є$ компетентнісно зорієнтована фізична i психофізіологічна підготовка (Ф і ПФП). Вона $€$ однією із форм творчого способу формування фізкультурно-оздоровчих компетентностей, то іiі 170 